RESEARCH PAPER

\title{
Evaluation of the use of wound-protectant fungicides and biological control agents against stem canker (Neofusicoccum parvum) of blueberry
}

\author{
Bernardo A. Latorre ${ }^{1}$, René Torres ${ }^{1}$, Tatiane Silva ${ }^{2}$, and Karina Elfar ${ }^{1}$ \\ ${ }^{1}$ Facultad de Agronomía e Ingeniería Forestal, Pontificia Universidad Católica de Chile. Vicuña Mackenna \\ 4860, Santiago, Chile. \\ ${ }^{2}$ Instituto Federal do Norte de Minas Gerais. Fazenda Sao Geraldo sn, Januária MG, Brazil.
}

\begin{abstract}
B.A. Latorre, R. Torres, T. Silva, and K. Elfar. 2013. Evaluation of the use of woundprotectant fungicides and biological control agents against stem canker (Neofusicoccum parvum) of blueberry. Cien. Inv. Agr. 40(3): 537-545. Economically, blueberry (Vaccinium corymbosum) has become a very important fruit crop in Chile, and stem canker (Neofusicoccum parvum) has frequently been observed as a major disease. The symptoms are characterized by partial or total death of the foliage associated with extensive reddish-brown canker lesions at the base of the stems. Pruning wounds appear to be the main infection route. In this study, fungicide pastes and biological control agents were evaluated for their effectiveness as pruning wound-protectants against $N$. parvum. The mycelium of $N$. parvum was highly sensitive to benomyl, tebuconazole, and iprodione in vitro, with median effective concentrations $\left(\mathrm{EC}_{50}\right)$ of $0.15-0.25,0.26-0.33$, and $0.52-0.68 \mu \mathrm{g} \cdot \mathrm{mL}^{-1}$, respectively. The pastes formulated with $0.1 \%$ benomyl, $0.5 \%$ tebuconazole, and $0.06 \%$ iprodione also provided considerable protection of pruning wounds against $N$. parvum on the stems of Duke blueberries under field conditions. However, pyraclostrobin, with relatively high $\mathrm{EC}_{50}$ values $\left(>2 \mu \mathrm{g} \cdot \mathrm{mL}^{-1}\right)$ in vitro, was largely ineffective in vivo at a $0.1 \%$ concentration, and $75 \%$ citrus extract (Citrus SL), Bacillus subtilis QST713 (Serenade Max), and Trichoderma spp. (Trichonativa) were also ineffective. Additionally, pastes formulated with 5\% boric acid, although effective, were phytotoxic.
\end{abstract}

Key words: Botryosphaeria canker, biological control, boric acid, ascorbic acid, Vaccinium corymbosum

\section{Introduction}

Blueberry (Vaccinium corymbosum L.) orchards extend from northern to southern Chile, currently comprising more than 12,000 ha. Among the blueberry diseases reported in Chile, stem canker

Received January 4, 2013. Accepted August 3, 2013. Corresponding author: blatorre@uc.cl caused by Neofusicoccum parvum (Pennycook \& Samuels) Crous, Slippers \& A.J.L. Phillips (tel. Botryosphaeria parva Pennycook \& Samuels) and other species of the family Botryosphaeriaceae has frequently been observed (Espinoza et al. 2009). These fungi are also very destructive pathogens on other hosts, e.g., grapevines, in Chile (Díaz et al., 2013; Morales et al., 2012) and worldwide (Úrbez-Torres, 2011). 
The symptoms of the disease are characterized by partial or total death of the foliage, always associated with the presence of extensive reddish brown canker lesions at the base of the stems and the crowns of the plants. Internally, a vascular discoloration of the xylem characterizes diseased stems.

Pruning wounds are considered to be the main infection route (Úrbez-Torres, 2011; Úrbez-Torres and Gubler, 2011), such that protecting the wounds has been proposed as the only way to prevent infection. Although the effect of several fungicides against Botryosphaeriaceae species has been studied in perennial hosts (Bester et al., 2007; Brown-Rytlewski and McManus, 2000; Díaz and Latorre, 2013; Li et al., 1995; Luque et al., 2008; Ma et al., 2002; Pitt et al., 2012), there is little or no information on the efficacy of fungicide and biocontrol treatments against species of Botryosphaeriaceae that attack blueberries. Previously, Espinoza et al. (2009) demonstrated that isolates of N. parvum from blueberries were sensitive in vitro to fludioxonil and iprodione, but these fungicides were not tested under field conditions. The aim of this study was to evaluate the effectiveness of fungicide pastes and biological control agents as pruning wound protectants against $N$. parvum in blueberry.

\section{Materials and methods}

\section{Isolates}

$N$. parvum isolates B1-06 originally obtained from blueberry were used. For inoculation purposes, a mycelium of isolate B1-06 was obtained from a 10 day-old culture on potato dextrose agar acidified with $0.5 \mathrm{~mL}$ per liter of $90 \%$ lactic acid plus $0.005 \%$ tetracycline, $0.01 \%$ streptomycin, and $0.1 \%$ Igepal CO-630 (Sigma-Aldrich, MO, USA) (APDA). For in vitro studies, $N$. parvum isolates B1-06 and 5.5.4R1(2), both from blueberry, were used. The isolates were maintained on APDA at $5^{\circ} \mathrm{C}$.

\section{Fungicides}

Fungicides containing benomyl (Benex $50 \mathrm{WP}$, Arysta, Chile), iprodione (Iprodione $50 \mathrm{WP}$, Agrospec, Chile), pyraclostrobin (Podexal $5 \mathrm{AL}$ and Comet 250 EC, Basf, Chile), tebuconazole (Podaspec 5Al and Tebuconazole $250 \mathrm{WP}$, Agrospec, Chile), Bacillus subtilis QST713 (Serenade Max, Arysta LifeScience Chile), Trichoderma spp. (Trichonativa, Bionativa, Chile), ascorbic acid (Citrus SL, 75\% citrus extract, Agrospec, Chile), and boric acid were used. Additionally, paste formulations of benomyl (Benex $50 \mathrm{WP}$ ), iprodione, and boric acid were prepared using an aqueous suspension of vinyl acrylic paint (VAP) (Latex base, Sherwin Williams Chile, S.A, Santiago, Chile).

\section{In vitro test}

The sensitivity of the N. parvum B1-06 and 5.5.4 R1(2) isolates to benomyl, iprodione, pyraclostrobin, and tebuconazole was assessed on APDA amended with 0.025 to $2.0 \mu \mathrm{g} \cdot \mathrm{L}^{-1}$ of the respective fungicide (added after autoclaving the APDA). A mycelium plug (5 $\mathrm{mm}$ in diameter) was placed in the center of each of four $9 \mathrm{~cm}$ Petri plates per treatment. Non-amended APDA plates were used as the controls. The plates were incubated at $25^{\circ} \mathrm{C}$ for $48 \mathrm{~h}$ to measure the radial mycelial growth.

To study the conidial sensitivity to benomyl and tebuconazole, a conidial suspension was prepared in Eppendorf tubes (1.5 mL), adjusting the final concentration to 0.025 to $2.0 \mu \mathrm{g} \cdot \mathrm{L}^{-1}$ of the respective fungicide. Conidia were incubated for $18 \mathrm{~h}$ at $25^{\circ} \mathrm{C}$ prior to randomly observe at least 50 conidia per fungicide concentration per each of four replicates. Conidia were counted as germinated when a normal germ tube of at least the length of the conidia was obtained. 


\section{Bioassay}

Detached actively growing shoots $(<1$-yr-old $)$ $(\mathrm{n}=4)$ of blueberry (cv. 'O'Neal') were surfacedisinfected (75\% ethanol, $5 \mathrm{~min})$, then aseptically pruned. The pruning wounds were immediately sprayed with benomyl $(0.5,1.0$ and $1.5 \%)$, iprodione $(0.03,0.006$ and $0.1 \%)$, pyraclostrobin $(0.05,0.1$ and $0.5 \%)$ and tebuconazole $(0.1,0.5$ and $1.0 \%)$. After $24 \mathrm{~h}$, a mycelial plug (5 $\mathrm{mm}$ in diameter) of either isolate B1-06 or isolate 5.5.4 R1(2) of $N$. parvum was placed on the pruned stub and wrapped with Parafilm. The stems were placed vertically in a humid chamber ( $>90 \%$ relative humidity) at $20{ }^{\circ} \mathrm{C}$. The length of the necrotic lesions was determined after 12 days of incubation. An equal number of inoculated but non-treated pruning wounds were included as a control.

\section{Field trials}

Field trials were conducted in a commercial blueberry planting of cv. Duke in Santa Cruz (Colchagua Valley) in 2011 and 2012. Blueberry Duke and blueberry O'Neal were equally susceptible to $N$. parvum (data not shown). The blueberry plants were managed according to standard methods except that fungicides were not used.

In Trial 1 , blueberry stems at 1 year of age were pruned in October (spring), and three stems were selected in each of the four plants per treatment. A $3 \mathrm{~mm}$ mycelial plug from the APDA cultures of $N$. parvum was placed over the fresh pruning cut and wrapped immediately with Parafilm to avoid rapid dehydration. The pruning wounds were treated $24 \mathrm{~h}$ before inoculation with a paste containing (w/v) $1 \%$ benomyl, $0.06 \%$ iprodione, $0.1 \%$ pyraclostrobin, $0.5 \%$ tebuconazole, or $5 \%$ boric acid or liquid formulations of $10 \%$ Bacillus subtilis (QST 713), 0.5\% Trichoderma spp., or 75\% citrus extract (equivalent to $7.08 \%$ ascorbic acid). The fungicide concentrations were determined on the basis of the label recommendations. The paste fungicides were applied with the aid of a paintbrush using approximately $1 \mathrm{~mL}$ per pruning wound, and the liquid formulations were sprayed with a hand sprayer using a similar volume per pruning wound. An equal number of inoculated but non-treated pruning wounds were included as a control.

In Trial 2, the effect of conventional fungicides (benomyl, iprodione, pyraclostrobin, and tebuconazole) was further evaluated as paste and spray treatments. The fungicides were applied at the concentrations indicated above, and the pruning wounds were inoculated $24 \mathrm{~h}$ after the treatments. This trial was conducted in autumn (May).

In Trial 3, the persistence of benomyl and tebuconazole, the two best fungicides according to the previous trials, was studied against $N$. parvum on blueberry stems. For this purpose, the blueberry plants were pruned and inoculated as indicated above at 1 and 10 days after the fungicide treatments in the spring (October).

The length of the internal discoloration of the wood developing from the inoculation site was evaluated at 18 and 30 days after inoculation in Trials 1 and 2 and at 36 days after inoculation in Trial 3. The control efficacy (CE) was determined as $\mathrm{CE}=100-(100 \times \mathrm{MNL}-\mathrm{T}) / \mathrm{MNL}-\mathrm{UT}$, where $\mathrm{MNL}-\mathrm{T}=$ the mean necrotic lesion of the treated stems and MNL-UT = the mean length of the untreated control.

Re-isolations were performed on APDA. Three samples (approximately $5 \mathrm{~mm}$ in length) of diseased tissue per replicate were collected from the margins of necrotic lesions. The percent re-isolation was calculated as the number of positive isolations over the total number of samples plated on APDA.

\section{Experimental design and statistical analysis}

The effective concentration required to obtain a $50 \%\left(\mathrm{EC}_{50}\right)$ inhibition of the mycelial growth was estimated with a linear regression analysis 
in which $\mathrm{X}=$ the $\log$ fungicide concentration and $\mathrm{Y}=$ the probit $\%$ of the control.

In the bioassay, the fungicide treatments were randomly distributed in a complete randomized design with a $4 \times 2$ (fungicide concentration $\times$ isolates) factorial structure, with four replicates of one stem each. The data were Ln $(x+1)$ transformed before the statistical analysis, although the non-transformed data are presented.

The fungicide treatments in Trial 1 were arranged as a complete block design, with four replicates of three stems each as the experimental units. In Trial 2, the treatments were distributed as a complete $2 \times 4$ factorial design (application method $x$ fungicide) with four replicates. The re-isolation data were transformed as the square root of $\mathrm{x}+$ 0.5 prior to the statistical analysis, although the non-transformed data are presented. The data were subjected to an analysis of variance, and the means were evaluated with Tukey's test $(\mathrm{P} \leq 0.05)$ with the aid of SigmaStat 3.1 (Systat Software Inc., San Jose, CA).

\section{Results}

The mycelium of $N$. parvum isolates B1-06 and 5.5.4 R1(2) was highly sensitive to benomyl, with $\mathrm{EC}_{50}$ values of $0.15-0.25 \mu \mathrm{g} \cdot \mathrm{mL}^{-1}$, followed by tebuconazole, with $\mathrm{EC}_{50}$ values of 0.26-0.33 $\mu \mathrm{g} \cdot \mathrm{mL}^{-1}$, and iprodione, with $\mathrm{EC}_{50}$ values of $0.52-0.68 \mu \mathrm{g} \cdot \mathrm{mL}^{-1}$. The $\mathrm{EC}_{50}$ values obtained for pyraclostrobin were $>2 \mu \mathrm{g} \cdot \mathrm{mL}^{-1}$ (Table 1).
The germination of the conidia was also highly sensitive to benomyl and tebuconazole, with $\mathrm{EC}_{50}$ values of 0.19-0.27 and 0.75-0.62 $\mu \mathrm{g} \cdot \mathrm{mL}^{-1}$, respectively (Table 1).

In the bioassay, using detached blueberry shoots, an analysis of variance showed that the isolates and the interaction between fungicide concentration and the isolates were not significant. However, a significant $(\mathrm{P} \leq 0.001)$ fungicide effect was obtained. The mean length of the necrotic lesions was reduced from $26.0 \mathrm{~mm}$ in the non-treated controls to 1.0 to $6.1 \mathrm{~mm}$ with benomyl, 1.4 to $7.5 \mathrm{~mm}$ with tebuconazol, 4.5 to $11.9 \mathrm{~mm}$ with iprodione and 3.2 to $18.8 \mathrm{~mm}$ with pyraclostrobin. Independently of the fungicide, the best control was obtained using the highest concentration (Figure 1).

In the initial screening of protectant compounds against $N$. parvum in blueberry stems, $0.5 \%$ tebuconazole (Podaspec), $0.1 \%$ benomyl, and $0.06 \%$ iprodione were, in order of efficacy, the most effective fungicide treatments. These fungicides completely prevented the re-isolation of $N$. parvum and provided greater than $90 \%$ control efficacy. The treatments had a significant $(\mathrm{P} \leq 0.001)$ effect on the mean length of the necrotic lesions (Figure 2), varying from $30.1 \mathrm{~mm}$ in the non-treated controls to $0.6,1.2$, and $3.2 \mathrm{~mm}$ for the pruning wounds treated with tebuconazole, benomyl, and iprodione, respectively. Pyraclostrobin, applied at $0.1 \%$, provided a relatively weak control $(\mathrm{CE}=$ $44.5 \%$ ), with a mean necrotic lesion length of 16.7 $\mathrm{mm}$, and N. parvum was re-isolated from the pruning wounds treated with pyraclostrobin (Table 2).

Table 1. Sensitivity of Neofusicoccum parvum isolates obtained from stem cankers of blueberries to fungicides with different modes of action.

\begin{tabular}{|c|c|c|c|c|c|}
\hline \multirow[b]{3}{*}{ Fungicide } & \multirow[b]{3}{*}{ Fungicide group } & \multicolumn{4}{|c|}{$\begin{array}{l}\text { Median effective concentration } \\
\qquad \mathrm{EC}_{50}, \mu \mathrm{g} \cdot \mathrm{mL}^{-1}\end{array}$} \\
\hline & & \multicolumn{2}{|c|}{ Mycelium } & \multicolumn{2}{|c|}{ Conidia } \\
\hline & & B1-06 & 5.5.4 R1(2) & B1-06 & 5.5.4 R1(2) \\
\hline Benomyl & Benzimidazole & 0.25 & 0.15 & 0.19 & 0.27 \\
\hline Iprodione & Dicarboximide & 0.68 & 0.52 & nd & nd \\
\hline Pyraclostrobin & $\mathrm{QoI}^{1}$ & $>2.0$ & $>2.0$ & nd & nd \\
\hline Tebuconazole & $\mathrm{DMI}^{1}$ & 0.26 & 0.33 & 0.75 & 0.62 \\
\hline
\end{tabular}

${ }^{1} \mathrm{QoI}=$ quinone outside inhibitor. $\mathrm{DMI}=$ sterol demethylation inhibitor. $\mathrm{nd}=$ not determined. 
A moderate control, $\mathrm{CE}=53.8 \%$, was obtained using 5\% boric acid. Ascorbic acid (Citrus SL), Bacillus subtilis, and Trichoderma spp. provided weak protection $(\mathrm{CE}<30.9 \%)$ of pruning wounds against infection by $N$. parvum on blueberry stems (Table 2). Similar results were obtained in a second experiment using these biological products (data not shown).

On the basis of the necrotic lesions obtained on the blueberry stems in Trial 2, an analysis of variance showed that the differences between the paste and liquid applications were not significant $(\mathrm{P}=0.582)$. However, the fungicide factor and the interaction between the application method and fungicide were significant $(\mathrm{P} \leq 0.0001)$ (Table $3)$. Based on the re-isolations of $N$. parvum from diseased tissues, a significant $(\mathrm{P} \leq 0.0001)$ effect was obtained for the application method and fungicide, and the interaction between the application method and fungicide was significant

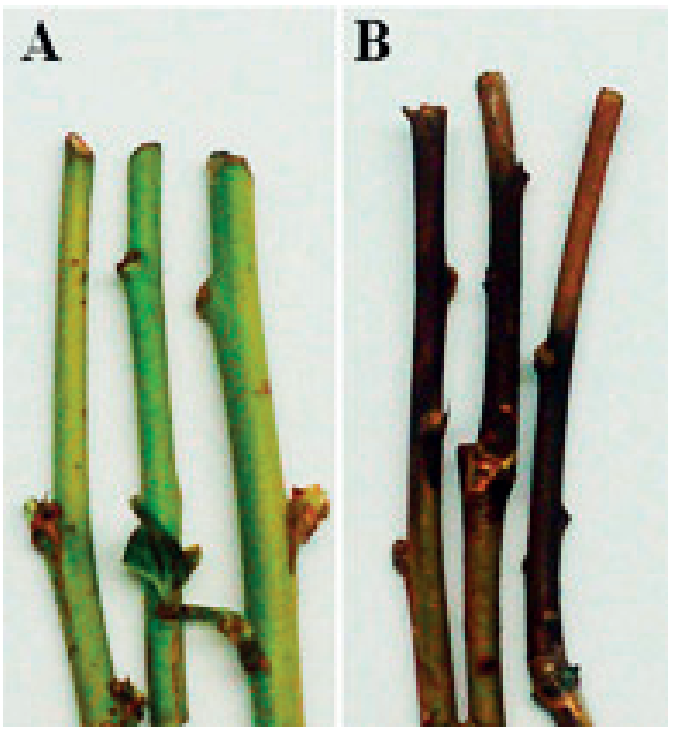

Figure 2. Control of stem canker (Neofusicoccum parvum) on inoculated stems of blueberry (Vaccinium corymbosum) $\mathrm{cv}$. Duke. A. Inoculated pruning wounds protected with benomyl. B. Non-protected pruning wounds that developed reddish-brown lesions after 36 days under field conditions. Discussion $(\mathrm{P} \leq 0.0001)$ (Table 3).
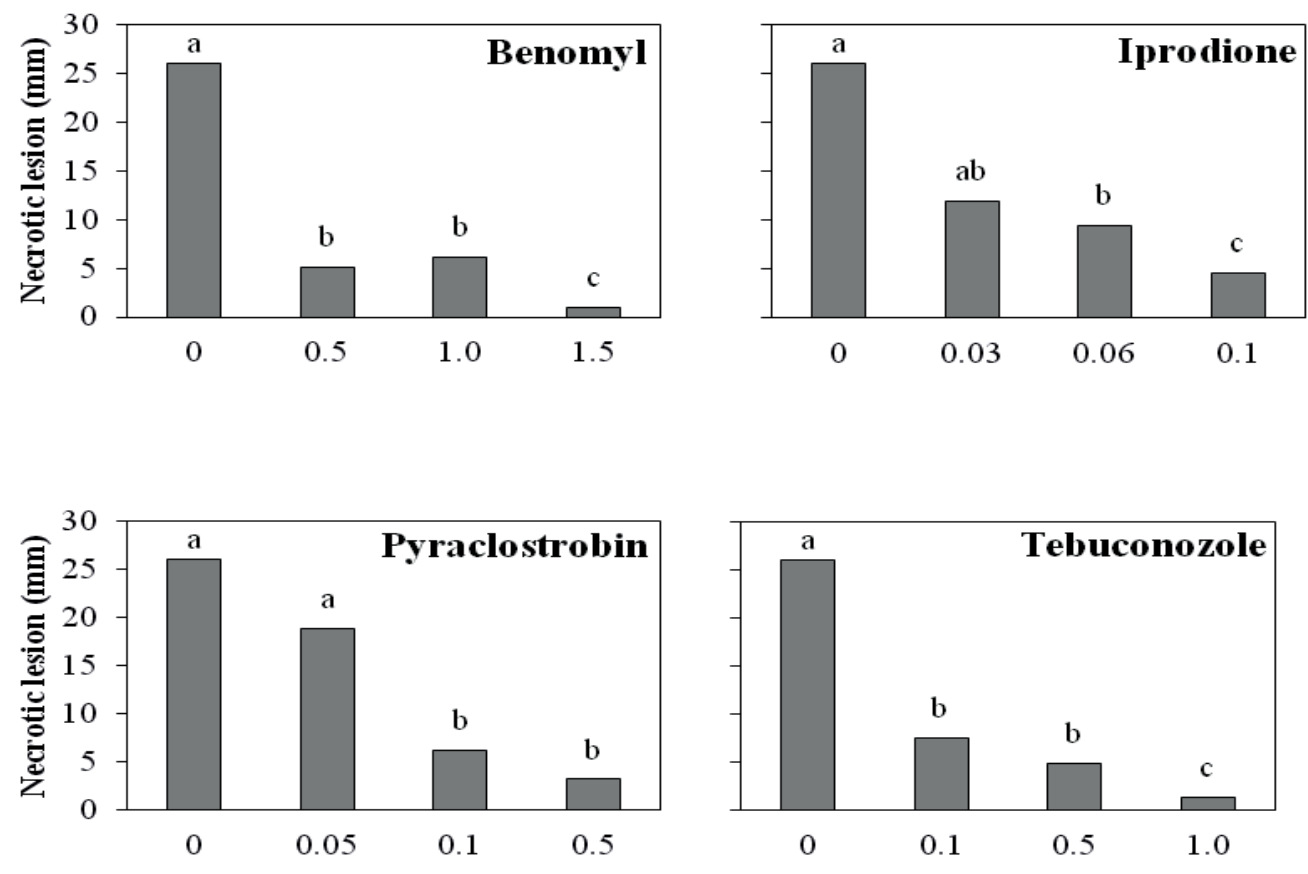

Fungicide concentration (\%)

Fungicide concentration $(\%)$

Figure 1. Effectiveness of fungicide spray applications as wound protectants against Neofusicoccum parvum infection in detached actively growing shoots of blueberry 'O'Neal'. The bars followed by the same letters are not significantly different according to Tukey's test $(\mathrm{P}=0.05)$. 
Table 2. Effect of fungicide treatments against Neofusicoccum parvum on pruning wounds of blueberry 'Duke' treated $24 \mathrm{~h}$ prior to inoculation.

\begin{tabular}{|c|c|c|c|c|c|}
\hline Fungicide & Origin & $\begin{array}{c}\text { Active } \\
\text { ingredient }\end{array}$ & $\begin{array}{c}\text { Rate }^{1} \\
\%\end{array}$ & $\begin{array}{c}\text { Necrotic } \\
\text { lesions }^{2} \\
\mathrm{~mm}\end{array}$ & $\begin{array}{c}\text { Re-isolation } \\
(\mathrm{n}=3) \\
\text { no. }\end{array}$ \\
\hline Podaspec, paste & Agrospec, Chile & Tebuconazole & 0.5 & $0.6 \mathrm{a}^{6}$ & $0.0 \mathrm{a}^{6}$ \\
\hline Benomyl, paste ${ }^{4}$ & & Benomyl & 0.1 & $1.2 \mathrm{a}$ & $0.0 \mathrm{a}$ \\
\hline Podexal, paste & Basf, Chile & Pyraclostrobin & 0.1 & $16.7 \mathrm{~b}$ & $1.0 \mathrm{~b}$ \\
\hline Iprodione, paste ${ }^{4}$ & & Iprodione & 0.06 & $3.2 \mathrm{a}$ & $0.0 \mathrm{a}$ \\
\hline Serenade WP & Arysta, Chile & $\begin{array}{l}\text { Bacillus subtilis } \\
\quad \text { (QST 713) }\end{array}$ & 10.0 & $24.4 \mathrm{c}$ & $3.0 \mathrm{c}$ \\
\hline Trichonativa & Bionativa, Chile & Trichoderma spp. & 0.5 & $21.2 \mathrm{bc}$ & $1.5 \mathrm{bc}$ \\
\hline Citrus $\mathrm{SL}^{5}$ & Agrospec, Chile & Ascorbic acid & 7.1 & $20.8 \mathrm{bc}$ & $1.3 \mathrm{bc}$ \\
\hline Boric paste ${ }^{4}$ & & Boric acid & 5.0 & $13.9 \mathrm{~b}$ & $0.0 \mathrm{a}$ \\
\hline Non-treated & & & - & $30.1 \mathrm{c}$ & $1.3 \mathrm{cb}$ \\
\hline
\end{tabular}

${ }^{1}$ Rate $=\%$ concentration of active ingredients used in this study.

${ }^{2}$ Necrotic lesions were determined 18 days after the inoculation. Inoculations were performed using a mycelial plug at $24 \mathrm{~h}$ after the fungicide application.

${ }^{3} \mathrm{Re}$-isolations were conducted on APDA using three small samples of stem tissue collected from the margins of the necrotic lesions at 18 days after the inoculation.

${ }^{4}$ Paste formulations were prepared for this study using aqueous suspensions of vinyl acrylic paint (Latex base, Sherwin Williams Chile, S.A).

${ }^{5}$ Citrus SL is a $75 \%$ citrus extract product equivalent to $7.1 \%$ ascorbic acid.

${ }^{6}$ The means of four replicates followed by the same letters are not significantly different according to Tukey's test $(\mathrm{P}=0.05)$. Reisolation data were transformed via the square root of $x+0.5$ prior to the analysis, but the non-transformed data are presented here.

Table 3. Analysis of variance showing the effect of the application method and fungicide on the length of necrotic lesions on the stems of blueberry 'Duke' caused by Neofusicoccum parvum.

\begin{tabular}{lcc}
\hline Treatment & $\begin{array}{c}\text { Necrotic lesions } \\
\mathrm{mm}\end{array}$ & $\begin{array}{c}\text { Re-isolation } \\
\text { no. }\end{array}$ \\
\hline Application method (AP) & & \\
Paste & 2.1 & 1.2 \\
Liquid & 1.9 & 1.6 \\
df & 1 & 1 \\
F & 0.31 & 43.2 \\
P & 0.582 & $<0.001$ \\
SED & 0.33 & 0.09 \\
Fungicide (F) & & \\
Benomyl & 0.06 & 0.0 \\
Iprodione & 1.95 & 1.5 \\
Pyraclostrobin & 3.06 & 2.5 \\
Tebuconazole & 0.00 & 0.0 \\
Untreated & 4.67 & 3.0 \\
df & 4 & 4 \\
F & 31.79 & 188.55 \\
P & $<0.001$ & $<0.001$ \\
SED & 0.51 & 0.14 \\
AM x F interaction & & \\
df & 4 & 4 \\
F & 23.93 & 43.95 \\
P & 0.0001 & $<0.001$ \\
SED & & 0.20 \\
\hline & 0.72 &
\end{tabular}

${ }^{1}$ Re-isolation $=$ the number of samples yielding $N$. parvum on APDA using three samples per replicate.

${ }^{2} \mathrm{SED}=$ standard error of the difference.
According to the length of the necrotic lesions, benomyl and tebuconazole effectively protected wounds against infection by N. parvum if the pruning wounds were inoculated 1 or 10 days after treatment (Figure 3). Inoculation performed 1 or 10 days after fungicide treatment provided greater than $97 \%$ CE. Independently of the application method, re-isolation was completely inhibited by benomyl and tebuconazole with inoculation at 1 and 10 days after fungicide application.

Stem canker has been recognized as a major disease of blueberry and is caused by N. parvum and other species of the family Botryosphaeriaceae. In this study, the inoculated but non-treated stems developed a brown-reddish necrosis (Figure 2) extending downward from the site of inoculation, as described for this disease in a previous study (Espinoza et al., 2009). The length of the necrotic lesions was considerably affected by the date of the inoculation. The longest lesions resulted from spring inoculations. Therefore, blueberry stems were susceptible to infection by N. parvum, but their susceptibility varied considerably between spring 
and autumn inoculations. However, it remains to be determined whether this effect was due to the physiological conditions of the host plant and/or the weather conditions, e.g., the temperature at the time of the inoculation. Re-isolation of $N$. parvum was equally successful in blueberries inoculated in the spring and in the autumn.

According to the results obtained in three trials conducted in Colchagua Valley in two consecutive years, stem canker can be considerably reduced by protecting pruning wounds with fungicides. Pruning wounds, as has been suggested for grapevines (Rolshausen et al., 2010; Úrbez-Torres and Gubler, 2011), appear to be the main route of $N$. parvum infection in blueberry. In the present study, benomyl, tebuconazole, and iprodione were the most effective fungicides against $N$. parvum.

Previous studies have demonstrated that benzimidazole compounds are highly effective against species of Botryosphaeriaceae on grapevines (Kotze et al., 2011; Pitt et al., 2012), Japanese apricots, peaches (Li et al., 1995), and oaks (Luque et al., 2008). However, to our knowledge, this is the first report demonstrating the efficacy of benomyl as a pruning wound protectant against infection caused by $N$. parvum on blueberry stems.
The effectiveness of sterol demethylation inhibitors (DMI) against species of Botryosphaeriaceae varies considerably among DMI compounds, and in general conidia are less sensitive than mycelium in vitro (Torres et al., 2013). In this study, the $0.5 \%$ tebuconazole treatments provided a strong control as a pruning wound protectant against $N$. parvum on blueberry stems. Similarly, tebuconazole has also been reported to be effective in reducing the infection caused by other Botryosphaeriaceae spp. on other hosts (Bester et al., 2007; Ma et al., 2002). However, other DMI compounds, e.g., penconazole, myclobutanil, and tetraconazole, were unable to protect pruning wounds from infection caused by Botryosphaeriaceae spp. (Pitt et al., 2012).

The low efficacy (44.5\%) obtained with the use of $0.1 \%$ pyraclostrobin in the field trials agreed with the relatively high $\mathrm{EC}_{50}\left(>2 \mu \mathrm{g} \cdot \mathrm{mL}^{-1}\right)$ obtained for the mycelial growth inhibition of $N$. parvum in vitro. A relatively low sensitivity of $N$. parvum isolates against pyraclostrobin has been reported previously (Pitt et al., 2012). However, it is still possible that considerable variation may occur among $N$. parvum isolates in nature, and it is also possible that the efficacy of pyraclostrobin can be improved if concentrations higher than $0.1 \%$ are used.
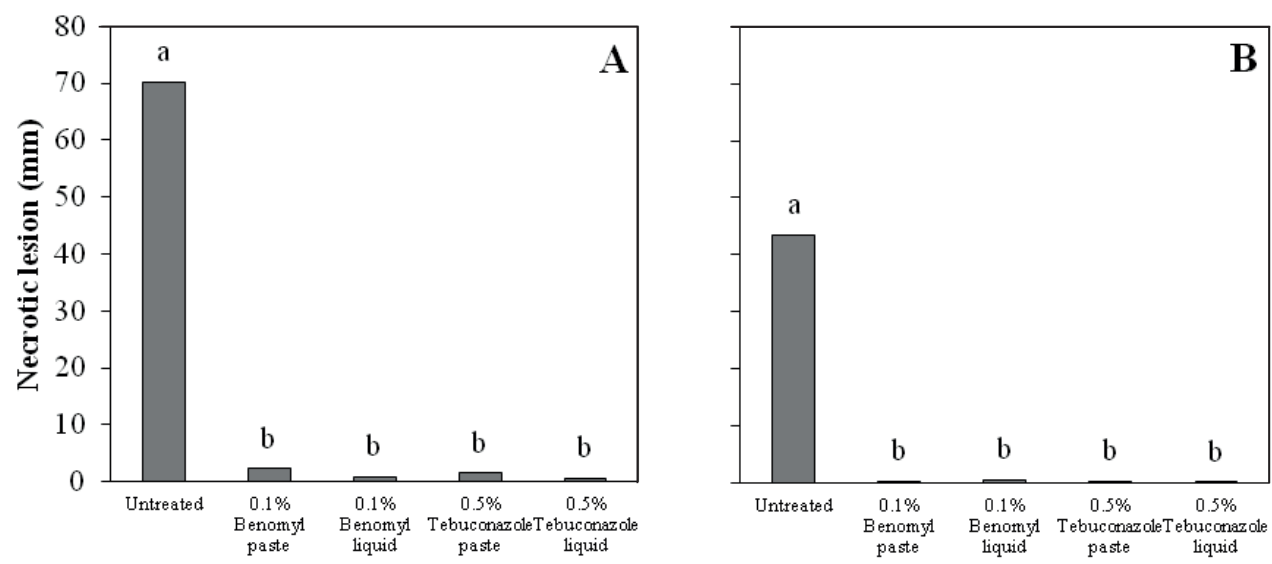

Figure 3. Effect of paste and liquid applications of fungicides as wound protectants for the prevention of Neofusicoccum parvum infection of blueberry pruning wounds. Pruning wounds were inoculated 1 day (A) and 10 days (B) after fungicide application. The bars followed by the same letters are not significantly different according to Tukey's test $(\mathrm{P}=0.05)$. 
It has been postulated that the healing process occurring in wounds reduces the susceptibility of pruning wounds to infection caused by several filamentous fungi in different host plants (Eskalen et al., 2007; Úrbez-Torres and Gubler, 2011). In the present study, the pruning wounds were very susceptible to $N$. parvum immediately after pruning in October, although they were still susceptible to infection caused by $N$. parvum when inoculation was performed at 10 days after pruning.

A wound-protectant paste prepared with boric acid has been tested in previous studies against species of Botryosphaeriaceae and Eutypa lata (Pitt et al., 2012; Rolshausen, and Gubler, 2005) on grapevines, providing good control under field conditions. Nevertheless, boric acid appears to be ineffective against Botryosphaeriaceae spp. in vitro (Pitt et al., 2012). In the present study, $5 \%$ boric acid completely inhibited $N$. parvum in vivo, and $0 \%$ re-isolation was obtained after 18 days of treatment. Therefore, the observed necrotic lesions were associated with phytotoxicity.

In conclusion, the results demonstrate that the occurrence of $N$. parvum-caused stem canker on blueberry can be reduced by protecting pruning wounds with fungicides (e.g., benomyl, iprodione, tebuconazole). Pruning wounds are susceptible to infection caused by $N$. parvum immediately after pruning, but additional research is needed to determine the efficacy of fungicides over time using conidia in addition to mycelia as the primary inoculum. The biological control agents and natural products tested were relatively ineffective against $N$. parvum.

\section{Acknowledgments}

The authors are very grateful for the financial support received from Comisión Nacional de Investigación Científica y Tecnológica (Conicyt) de Chile through Fondecyt project 1100246.

\section{Resumen}

B.A. Latorre, R. Torres, T. Silva y K. Elfar. 2013. Evaluación de fungicidas y agentes biocontroladores como protectores de heridas contra la cancrosis del tallo (Neofusicoccum parvum) del arándano. Cien. Inv. Agr. 40(3): 537-545. El arándano (Vaccinium corymbosum) se ha convertido en un cultivo de fruta económicamente muy importante para Chile. Entre las enfermedades que lo afectan, la cancrosis del tallo (Neofusicoccum parvum) ha adquirido gran importancia. Los síntomas se caracterizan por una muerte parcial o total del follaje, asociado a lesiones cancrosas café rojizas que afectan externa e internamente en la base de los tallos. Se acepta que la infección se inicia a través de las heridas de poda. Este estudio tuvo como principal objetivo evaluar la eficacia de pastas fungicidas para la protección de las heridas contra $N$. parvum en arándanos. Los resultados obtenidos demostraron que el micelio de $N$. parvum es muy sensible a los fungicidas benomilo, tebuconazol e iprodione in vitro, con concentraciones medianas efectivas $\left(\mathrm{EC}_{50}\right)$ de $0,15-0,25 ; 0,26-0,33$ y $0,52-0,68 \mu \mathrm{g} \cdot \mathrm{mL}^{-1}$, respectivamente. En condiciones de campo, las pastas fungicidas formuladas con $0,1 \%$ de benomilo, $0,5 \%$ de tebuconazol o 0,06\% de iprodione otorgaron una protección considerable de las heridas de poda contra $N$. parvum en los tallos de arándanos cv. Duke. Pyraclostrobin, con valores de $\mathrm{EC}_{50}>2$ $\mu \mathrm{g} \mathrm{mL}^{-1}$ in vitro, fue relativamente ineficaz in vivo al utilizarlo en una concentración de $0,1 \%$. Del mismo modo, 75\% de extracto cítrico (Citrus SL), Bacillus subtilis QST713 (Serenade 
Max) y Trichoderma spp. (Trichonativa) fueron ineficaces contra N. parvum. Además, las pastas formuladas con 5\% de ácido bórico, aunque eficaces, resultaron fitotóxicas.

Palabras clave: Acido ascórbico, ácido bórico, Botryosphaeria, cancro, control biológico, Vaccinium corymbosum.

\section{References}

Bester, W., P.W. Crous, and P.H. Fourie. 2007. Evaluation of fungicides as potential grapevine pruning wound protectants against Botryosphaeria species. Australas. Plant Pathol. 36:73-77.

Brown-Rytlewski, D.E., and P.S. McManus. 2000. Virulence of Botryosphaeria dothidea and Botryosphaeria obtusa on apple and management of stem cankers with fungicides. Plant Dis. 84:1031-1037.

Díaz, G.A., and B.A. Latorre. 2013. Efficacy of paste and liquid fungicide formulations to protect pruning wounds against pathogens associated with grapevine trunk diseases. Crop Protection 46:106-112.

Eskalen, A., A.J. Feliciano, and W.D. Gubler. 2007. Susceptibility of grapevine pruning wounds and symptom development in response to infection by Phaeoacremonium aleophilum and Phaeomoniella chlamydospora. Plant Dis. 91:11001104.

Espinoza, J.G., E.X. Briceño, E.R. Chávez, J.R. Úrbez-Torres, and B.A. Latorre. 2009. Neofusicoccum spp. associated with stem canker and dieback of blueberry in Chile. Plant Dis. 93:11871194.

Kotze, C., J. van Niekerk, L. Mostert, F. Halleen, and P. Fourie. 2011. Evaluation of biocontrol agents for grapevine pruning wound protection against trunk pathogen infection. Phytopathol. Mediterr. 50:S247-S263.

Li, H.-Y., R.-B. Cao, and Y.-T. Mu. 1995. In vitro inhibition of Botryosphaeria dothidea and Lasiodiplodia theobromae, and chemical control of gummosis disease of Japanese apricot and peach trees in Zhejiang Province, China. Crop Prot. 14:187-191.
Luque, J., J. Pera, and J. Parlade. 2008. Evaluation of fungicides for the control of Botryosphaeria corticola on cork oak in Catalonia (NE Spain). Forest Pathol. 38:147-155.

Ma, Z., D.P. Morgan, D. Felts, and T.J. Michailides. 2002. Sensitivity of Botryosphaeria dothidea from California pistachio to tebuconazole. Crop Prot. 21:829-835.

Morales, A., B.A. Latorre, E. Piontelli, and X. Besoain. 2012. Botryosphaeriaceae species affecting table grape vineyards in Chile and cultivar susceptibility. Cien. Inv. Agr. 39:445-458.

Pitt, W.M., M.R. Sosnowski, R. Huang, Y. Qiu, C.C. Steel, and S. Savocchia. 2012. Evaluation of fungicides for the management of Botryosphaeria canker of grapevines. Plant Dis. 96:1303-1308.

Rolshausen, P.E., and W.D. Gubler. 2005. Use of boron for the control of Eutypa dieback of grapevines. Plant Dis. 89: 734-738.

Rolshausen, P.E., J.R. Úrbez-Torres, S. RooneyLatham, A. Eskalen, R.J. Smith, and W.D. Gubler, 2010. Evaluation of pruning wound susceptibility and protection against fungi associated with grapevine trunk diseases. Am. J. Enol. Vitic. 61:113-119.

Torres, C., B.A. Latorre, P. Undurraga, and X. Besoain. 2013. Evaluation of DMI fungicides against species of Diplodia and Neofusicoccum associated with Botryosphaeria canker of grapevine. Cien. Inv. Agr. 40:131-138.

Úrbez-Torres, J.R. 2011. The status of Botryosphaeriaceae species infecting grapevines. Phytopathol. Mediterr. 50:S5-S44.

Úrbez-Torres, J.R., and W.D. Gubler. 2011. Susceptibility of grapevine pruning wound to infection by Lasiodiplodia theobromae and Neofusicoccum parvum. Plant Pathol. 60:261-270. 
